\title{
Do Developing Countries Have a Say? Bilateral and Regional Intellectual Property Negotiations with the EU
}

\author{
Anke Moerland
}

(C) The Author(s) 2017. This article is an open access publication

\begin{abstract}
Bilateral and regional agreements concluded with the European Union (EU) and the United States are extensive and include high levels of IP protection and enforcement standards. Such protection is crucial to enhance their competitiveness, but it does not seem to be a priority for developing countries (DCs). This paper analyses how DCs should best address trade negotiations in which high standards of IP protection and enforcement are sought and few balancing (safeguard and flexibility) provisions, or such that can stimulate technology transfer, are on offer. The Max Planck Institute for Innovation and Competition's "Principles for Intellectual Property Provisions in Bilateral and Regional Agreements" cover many issues that are worth discussing as to how these can be incorporated in the negotiating process. Data collected from the CARIFORUM region when negotiating the EU-CARIFORUM Economic Partnership Agreement reconfirm the Principles' main recommendations; so do the experiences from India, Central American countries, Colombia and Peru in negotiations with the EU. The argument made here, however, is that a crucial factor in achieving more favourable outcomes for DCs is through an increase of their bargaining power. It will be examined what structural factors influence bargaining power and how this impacts the use of negotiating strategies.
\end{abstract}

Keywords The Caribbean · CARIFORUM - Developing countries · European Union · Regionalism · TRIPS-plus

\footnotetext{
A. Moerland $(\bowtie)$

Assistant Professor of Intellectual Property Law, Maastricht University, Maastricht, The Netherlands

e-mail: anke.moerland@maastrichtuniversity.nl
} 


\section{Introduction}

Developing countries ${ }^{1}$ (and less so least-developed countries) regularly negotiate international trade agreements, both among each other but also with developed countries, such as the United States (US) and the European Union (EU). In negotiations with the US or the EU, developing countries (DCs) must be prepared, among others, to negotiate extensive chapters that contain high levels of intellectual property (IP) protection and enforcement standards. ${ }^{2}$ While strong IP protection and enforcement is key for developed countries, ${ }^{3}$ it does not seem to be a priority of trading partners that are DCs. Depending on the level on which they make use of the IP system and offer IP protection, ${ }^{4}$ these countries might rather want to focus on safeguard provisions, flexibilities, limitations to intellectual property (IP) rights, provisions reinforcing technology transfer and cooperation with companies in partner countries. Arguably, it is under these conditions that they are able to benefit most from IP protection and enforcement. However, these areas are not prominently addressed in recent bilateral and regional agreements (BRAs).

This article analyses how DCs should best address negotiations in which high standards of IP protection and enforcement are sought and few balancing (safeguard and flexibility) provisions, or such that can stimulate technology transfer, are on offer. The Max Planck Institute for Innovation and Competition's "Principles for Intellectual Property Provisions in Bilateral and Regional Agreements" (hereinafter "Max Planck Principles") $)^{5}$ cover many issues that are worth discussing as to how they can be incorporated in the negotiating process. In Part 2, the article first analyses the main challenges that DCs face when negotiating the IP chapters of recent BRAs with the EU. It is only after 2006 that the EU has started to include TRIPS-plus provisions in its BRAs; compared to the US, its approach is similarly aggressive and still on going in several negotiations with third parties. In Part 3, the recommendations suggested by the Max Planck Principles are discussed in the light of the CARIFORUM ${ }^{6}$ region's experience when negotiating the CARIFORUM-EC Economic Partnership Agreement (EPA). The data on which the analysis is based was collected mainly through semi-structured interviews with approximately 30 state and non-state actors in the Caribbean region in 2010. Finally, the author argues

\footnotetext{
${ }^{1}$ Acknowledging that a general definition of developing countries is lacking, yet commonly used, I chose to use the term as a proxy for referring to countries that overall do not yet make full use of the intellectual property system and/or have weak IPR protection. Such countries are likely to fall under the World Bank income groupings low, lower-middle or upper-middle income group, which generally may come under the term developing countries. Yet, a clear delineation is not possible as for some areas, even high income countries could have chosen to offer a relatively low level of IP protection, on which they face pressure during trade negotiations. The findings of the paper therefore are largely directed towards developing countries, but could also be relevant for specific IP areas or industries for developed countries.

${ }^{2}$ Hassan et al. (2010), p. xiii.

${ }^{3}$ European Commission (2006), p. 2.

${ }^{4}$ US Chamber of Commerce (2017).

${ }^{5}$ Max Planck Institute on Innovation and Competition (2013).

${ }^{6}$ CARIFORUM stands for the Caribbean Forum of African Caribbean and Pacific states and includes 15 countries.
} 
that a crucial factor in achieving more favourable outcomes for DCs is through an increase of their bargaining power. The examination will address which structural factors influence the bargaining power of negotiating partners, their influence on negotiating strategies, and which lessons have been learnt from the negotiations between the EU on the one hand, and India, Central American countries, Colombia and Peru as well as CARIFORUM countries on the other hand.

\section{IP Provisions in Recent EU Bilateral Trade Agreements}

During the last 20 years, the IP landscape in bilateral and regional agreements has been dominated by two main developments. First, the US has pursued the most aggressive approach in bilateral negotiations on IP protection. Not only the content of the IP chapter in its free trade agreements (FTAs), but also the process of negotiations is not comparable with the approach of any of the other major actors, such as the EU, Japan and members to the European Free Trade Agreement. In terms of content, the IP chapter contained in US FTAs sets out the highest standards of IP protection in most areas of IP covered by the Agreement on Trade-Related Aspects of Intellectual Property Rights (hereinafter TRIPS), the exception being the protection of geographical indications. The provisions relating to the protection of public health and to the access to digital works have been described as the most farreaching obligations. ${ }^{7}$ But also the rules on patent protection for plants and animals and the enforcement provisions hardly leave its negotiating partner any room for choosing the appropriate method of implementation. Regarding the negotiating process, the US applies a disputed "certification process" that assesses to what extent the standards agreed upon in the FTA are also implemented by their negotiating partner. ${ }^{8}$ Thereby, the influence of the US does not stop at the negotiating table, but extends to the implementation phase.

The other development that characterizes the bilateral and regional IP landscape is the recent shift in the EU's IP policy towards third countries. The policy has changed with regard to at least two aspects. First, a shift has occurred from regulating IP protection primarily through multilateral treaties to using the instrument of bilateral trade agreements for achieving the desired level of IP protection abroad. EU bilateral trade agreements concluded before 2006 contain only a few provisions on IP protection, an exception being the agreements on trade in wine and/or spirits. Instead of identifying specific obligations for different fields of IP protection, European "old generation" bilateral trade agreements refer to standards of protection indirectly by setting out a list of multilateral agreements with which negotiating partners need to comply or to which they are required to accede. One exception to the EU's multilateral approach is the area of geographical indications (GIs) and traditional expressions, in which the EU has offensive interests. EU bilateral agreements concluded before 2006 set out specific obligations which require a higher level

\footnotetext{
7 Abbott (2004); Morin (2006); Rossi (2006).

${ }^{8}$ Moerland (2013), p. 103; Roffe (2014), p. 23.
} 
of protection than the US. ${ }^{9}$ Since 2006, bilateral agreements contain detailed bilateral standards of protection for the various IP rights individually.

Second, the level of protection asked for by the EU has increased considerably. For more than a decade, the EU demanded that third countries abide by the TRIPS Agreement. Since 2006, however, the protection included in bilateral trade agreements has become of a TRIPS-plus nature. ${ }^{10}$

The EU's new external IP policy seems to follow, in many aspects, the aggressive stance taken by the US in its FTAs. ${ }^{11}$ The changes are both reflected in policy documents as well as in recent "new generation" agreements. They are in line with the goal set out in the "Global Europe" strategy" of using IP provisions in bilateral trade agreements to foster Europe's competitiveness. Already the scope of the IP chapters in the "new generation" bilateral trade agreements reflects the new focus on IP issues. For the first time, bilateral agreements contain specific chapters on the protection of intellectual property (and innovation). These chapters are very detailed as they deal with each IP right individually. The IP chapters consist of approximately 33 articles. This level of detail in regulating IP in bilateral trade agreements reflects an alignment with the style used by the US: the scope of protection contained in US FTAs is equally specific and detailed. The level of protection in the "new generation" agreements is achieved through a mixed approach. While the EU continues to ask its partner countries to accede to or comply with particular multilateral IP treaties, the new IP chapters now also and even predominantly address the various areas of IP individually, through specific provisions. This new approach by the EU, which follows the US approach, is presented according to four points in more detail below.

\subsection{IP Provisions as Part of a Package Deal in Trade Negotiations}

IP protection is not only an area of protection addressed at the periphery of trade negotiations between countries. A considerable amount of BRAs concluded worldwide contains IP provisions. A recent study conducted by the WTO Secretariat in $2014^{13}$ has identified how many agreements of the ones notified to the GATT/WTO ${ }^{14}$ include some content relating to IP protection and enforcement. Accordingly, from the 245 BRAs reported to the GATT/WTO until February 2014 and that are still in force, 174 agreements contain some type of IP provisions. ${ }^{15}$ It is particularly the agreements that entered into force after 2000 that have IP content: more than $80 \%$ of those include IP provisions, of

\footnotetext{
9 Moerland (2013), p. 142 ff.

${ }^{10}$ Moerland (2013), p. $185 \mathrm{ff}$.

11 Maskus (2006), p. 460.

12 European Commission (2006), p. 2.

13 Valdés and McCann (2014).

14 BRAs notified to the WTO include free trade agreements, customs unions or partial scope agreements in the areas of goods and services. They include the notifications made under Art. XXIV GATT 1994, Art. V GATS, the Enabling Clause, as well as accessions to existing RTAs.

15 Valdés and McCann (2014), p. 21.
} 
which the vast majority refers to specific IPR types. ${ }^{16}$ These agreements do not only deal with IP issues. They take the form of FTAs, addressing various areas of trade and allowing for so-called "package deals". ${ }^{17}$ Research has shown that enhanced IP protection and enforcement is often accepted by one negotiating partner as a trade-off for concessions by the other party in other areas: "Deals are driven by export interests and other objectives external to the IP system rather than the common goal to achieve a mutually advantageous, balanced regulation of IP among the parties." 18

Therefore, when IP standards are included in agreements, there is a real danger that countries accept less apt standards to their system in order to gain more in other areas, particularly when no impact assessment has been carried out.

\subsection{Prescriptive and Complex IP Rules with Little Regard for Flexibilities and Limitations}

The IP provisions included in recent BRAs are more extensive than multilateral standards agreed upon in the Paris Convention for the Protection of Industrial Property, the Berne Convention for the Protection of Literary and Artistic Works and the TRIPS. The latter agreements strike a balance between minimum standards of IP protection and enforcement on the one hand, and flexibilities and ceilings on the other hand. ${ }^{19}$ This balance is mostly absent in bilateral and regional agreements. ${ }^{20}$

In fact, IP provisions have become more detailed and prescriptive: they transplant specific protection and enforcement standards from the domestic IP system of the IP-demanding country. In particular, in recent EU agreements, most of the enforcement provisions (rules on evidence, provisional and precautionary measures, remedies, damages) included in the CARIFORUM-EC EPA, the EU-Colombia-Peru FTA and the draft India-EU BTIA (as proposed by the EU) are literally taken from the Enforcement Directive 2004/48 ${ }^{21}$ and the Customs Regulation 1383/2003. ${ }^{22}$ Also in the area of GIs, the EU has chosen to insert or propose identical provisions to those contained in the EC Regulation 510/2006 on the protection of GIs for agricultural products and foodstuffs to recent negotiating partners. In particular, the Regulation's provisions addressing the level of GI protection, ${ }^{23}$ exceptions, ${ }^{24}$ as

\footnotetext{
$\overline{16}$ Valdés and McCann (2014), p. 21.

17 Valdés and McCann (2014), p. 26.

18 Max Planck Institute on Innovation and Competition (2013), principle 1.

${ }^{19}$ Such a balance is not necessarily incorporated in other multilateral agreements. Examples of treaties that include substantial standards of protection are the International Convention for the Protection of New Varieties of Plants, as revised in Geneva on 19 March 1991, the WIPO Copyright Treaty and the WIPO Performances and Phonograms Treaty.

${ }^{20}$ Max Planck Institute on Innovation and Competition (2013), principle 4.

${ }^{21}$ See Arts. 7, 9-13 Enforcement Directive 2004/48.

${ }^{22}$ See Art. 2 Customs Regulation 1383/2003.

${ }^{23}$ See Art. 13.1 EC Regulation 510/2006.

${ }^{24}$ See Art. 3.2 EC Regulation 510/2006.
} 
well as the relationship with trade marks ${ }^{25}$ have found their way into the agreements concluded with CARIFORUM countries, Colombia-Peru and that being negotiated with India. ${ }^{26}$ Similarly, in the area of copyright protection, provisions identical to those used in EU legislation have been transposed into some "new generation" bilateral trade agreements. The Information Society Directive 2001/29 contains protection for technical protection measures, rights management information, ${ }^{27}$ and the rights on reproduction and communication to the public. ${ }^{28}$ Provisions thereon have been copy-pasted into the IP chapter proposed to India. ${ }^{29}$ Finally, the obligations in the area of design protection in recent bilateral trade agreements also show very similar language to that used in the EC Directive 89/71 on the legal protection of designs. In particular, its provisions on the definition of a design, ${ }^{30}$ the definition of the constituting element "individual character", 31 and the term of protection $^{32}$ have informed the equivalent rules in the agreements with CARIFORUM States and Central American countries, and the IP chapter proposed to India. ${ }^{33}$

Legal transplants (these are identical or almost identical provisions stemming from the internal legislation of the originating country) reflect the domestic preferences of the originating jurisdiction, in this case the EU. They are not necessarily adapted to the preferences of the receiving jurisdiction. As the prescriptive language used does not leave much policy space for adaptations during the implementation phase, the effect is that the provisions may stay extraneous to the system, and thereby not addressing domestic needs. This is particularly a challenge for DCs who have less capacity to address and mitigate the most pernicious effects of legal transplants.

In contrast to the detailed legal transplants regarding the IP obligations, it is important to note that the exceptions, limitations and other checks and balances present in the EU domestic system are mostly not transcribed into the BRA. The effect is that the country facing IP demands is left with a higher level of IP protection and enforcement than the IP-demanding country itself if its domestic law

\footnotetext{
25 See Art. 14 EC Regulation 510/2006.

${ }^{26}$ On the level of protection, see Art. 210.1 EU-Colombia-Peru FTA; Art. 9.42010 draft IP chapter India-EU BTIA, as proposed by the EU (note that the area of GI is not addressed in the $2013 \mathrm{draft}$, therefore the earlier draft of the EU-India BTIA from July 2010 has been used). On the exception addressing GIs that are identical to the name of a plant variety or animal bread, see Art. 145.C.2 CARIFORUM-EC EPA; Art. 9.3.2 2010 draft IP chapter India-EU BTIA, as proposed by the EU. On the relationship with trademarks, see Art. 211.1 EU-Colombia-Peru FTA; Art. 9.7.1 and 5 of the 2010 draft IP chapter India-EU BTIA, as proposed by the EU.

27 See Art. 6 and 7 Information Society Directive.

28 See Art. 2 and 3 Information Society Directive.

29 See Art. 7.4 ${ }^{\text {bis }}, 7.5,7.7$ and 7.8 draft IP chapter India-EU BTIA, as proposed by the EU.

30 See Art. 1(a) EC Directive 89/71.

31 See Art. 5.1 EC Directive 89/71.

32 See Art. 10 EC Directive 89/71.

33 See Art. 146.B.3 and 146.E.1 CARIFORUM-EC EPA; Art. 8.5 EU-Central America FTA; Art. 12.2 draft IP chapter India-EU BTIA, as proposed by the EU.
} 
does not provide for these safeguards. ${ }^{34}$ This is particularly so in the area of GIs and enforcement provisions.

Examples of omitted exceptions are two TRIPS exceptions ${ }^{35}$ in the area of GIs that are included in EU internal legislation. ${ }^{36}$ These concern the use of generic terms (EU-Colombia-Peru FTA and draft IP chapter India-EU BTIA) and homonymous GIs (EU-Colombia-Peru FTA, EU Central America AA). Important TRIPS flexibilities and safeguards, which can also be found in the Enforcement Directive, ${ }^{37}$ have been omitted from recent "new generation" agreements. These are the general principle on freedom of implementation, ${ }^{38}$ the safeguards relevant to rules on preserving evidence $^{39}$ as well as provisional ${ }^{40}$ and corrective measures. ${ }^{41}$

\subsection{Lack of Transparency and Public Participation}

The process of negotiating bilateral and regional agreements has been criticized by scholars, civil society organizations and society at large. ${ }^{42}$ The criticism specifically focuses on the lack of transparency, inclusiveness and equal participation of stakeholders and the public. One important consequence of this is that information on the content of the agreement is not available. Such secrecy can be in the interest of both negotiating partners, e.g. where a public debate on contentious issues is unwanted, neither within the EU nor among domestic actors in the partner country. But where the negotiating partner would be interested in sharing information but is not allowed to do so, ${ }^{43}$ the lack of available information makes it almost impossible to receive relevant information and advice from third parties in order to adjust their negotiating strategy. For several DCs, advice from third parties is crucial as

\footnotetext{
34 Max Planck Institute on Innovation and Competition (2013), principle 7.

35 Art. 23.3 and 24.6 TRIPS Agreement.

36 Art. 6.2 and 6.3 Regulation 1151/2012.

37 Art. 7 Enforcement Directive on the preservation of evidence; Art. 9.3, 9.5 and 9.6 Enforcement Directive on provisional measures and Art. 10.3 on the proportionality of corrective measures.

38 See Art. 41.5 TRIPS Agreement. It has been omitted in the draft IP chapter India-EU BTIA, the CARIFORUM-EC EPA and the EU-Central America AA. The provision has been included in Art. 234.4 EU-Colombia-Peru FTA.

39 Art. 153 CARIFORUM-EC EPA and Art. 229 EU-Colombia-Peru FTA. Only Art. 19 draft IP chapter India-EU BTIA (as leaked in September 2013) and Art. 262 EU-Central America AA do.

40 Art. 156 CARIFORUM-EC EPA, Art. 232 EU-Colombia-Peru FTA, and Art. 22.1 draft IP chapter India-EU BTIA (as leaked in September 2013) do not include the safeguards set out in Art. 50.3, 50.6 and 50.7 TRIPS Agreement and Art. 9.3, 9.5, 9.6 and 9.7 Enforcement Directive 2004/48. They relate to the power of judicial authorities to require additional evidence from the applicant, to provide a security, to honour a request to revoke the provisional measure if no proceedings on the merits had been started and to grant appropriate compensation to the defendant. Only Art. 265 EU-Central America AA does.

41 Art. 157 CARIFORUM-EC EPA, Art. 241 EU-Colombia-Peru FTA do not include the need to secure proportionality when imposing corrective measures, as set out in Art. 46 TRIPS Agreement. On the other hand, Art. 23 draft IP chapter EU-India BTIA and Art. 266.1(b) EU-Central America AA provide for this safeguard.

42 BIOTHAI (2008), p. 28; Kuanpoth (2006), p. 29; Oxfam America (2003), p. 6; Vivas-Eugui (2003), p. 15 .

43 El-Said (2007), p. 170.
} 
domestic constituents often lack the necessary expertise. ${ }^{44}$ Official information is either not made public at all or merely in summary version just before or after the agreement has been signed. The EU in fact makes negotiating mandates available, but not the negotiating texts. In many cases, such draft negotiating texts may be leaked via channels that have not been authorized by the negotiating partners. ${ }^{45}$ However, these texts are not always leaked in time for stakeholders to react to them. Furthermore, the exact date from which they stem is often unknown and one cannot rely on such information to correctly reflect the state of negotiations at that stage.

Another consequence is that preferences of only particular stakeholders are heard and discussed during the process of negotiations. As a result, the final text of the agreements will not be the outcome of a process where different interests prevalent in society compete with each other for influence. It is, however, this latter struggle for influence that should inform policy choices on both sides of the negotiating table. This is ever more relevant where the text of the agreement contains legal transplants. $^{46}$

\subsection{Few Concrete Provisions on Licensing and Cooperation Arrangements}

In light of the strong IP protection present in the chapters, the absence of complementary rules on licensing or cooperation arrangements impacts the possibility for technology transfer negatively. In particular, legal obligations surrounding licensing are hardly or with little commitment included in such agreements. This is problematic as the control of adverse licensing practices often can inhibit technology transfer. The same is true for cooperation arrangements between industries from the EU and in partner countries: they are either absent or unspecific and non-binding. Even though it is difficult to ensure industry support, bilateral and regional trade agreements are excellent opportunities to specify the obligations firms from the EU could take up, e.g. in terms of funding for specific transfer of technology programs. ${ }^{47}$ The absence of such concrete commitments has also been lamented with regard to the implementation of Art. 66.2 TRIPS, which without concrete obligations do not create meaningful results for transferring technology. The same destiny will apply to BRAs that lack concrete commitments.

The CARIFORUM-EC EPA provides an example where efforts have been made to address issues of technology transfer, cooperation arrangements and licensing practices. ${ }^{48}$ However, while these attempts have been appreciated as being the first to suggest bilateral provisions on technology transfer, at the same time, they have been criticized for not being specific enough and merely including soft obligations, for example, the exchange of views, the sharing of information and using language

\footnotetext{
44 Moerland (2013), p. 576.

45 An example are the draft versions of the Anti-Counterfeiting Trade Agreement.

46 Max Planck Institute on Innovation and Competition (2013), principle 10.

47 Abbott (2014), p. 168.

48 See Art. 134, 135.2.(d) and (f), 142.1 and 142.3 CARIFORUM-EC EPA.
} 
such as "promoting" partnerships for research and development activities and "facilitating" support for technical assistance. ${ }^{49}$

According to Art. 142.3 CARIFORUM-EC EPA, the European Union shall promote and facilitate the use of incentives for technology transfer to all CARIFORUM States. While the technical negotiator of IP issues Malcolm Spence stresses that it has been an interest of CARIFORUM States to (1) extend the use of incentives, rather than incentives as such, to (2) all CARIFORUM States, rather than to least developed countries only, the provision loses some of its strength because of the type of obligation agreed upon: the EU shall "facilitate and promote" the use of such incentives and is not obliged to provide them.

The same is true regarding the cooperation arrangements in the CARIFORUMEC EPA: while Art. 134 identifies the relevant programmes under which CARIFORUM firms could participate, the obligation is one of facilitating and promoting such use. Accordingly, Art. 134 of the CARIFORUM-EC EPA requires parties to facilitate and promote the participation of CARIFORUM States in existing and future framework programmes, ${ }^{50}$ specific programmes and other activities of the European Union. Even though the obligation is rather soft, so far, no other bilateral partner country was able to obtain access to such programmes for its firms. In addition, it identifies the relevant programmes clearly enough for CARIFORUM firms to rely upon them. This obligation has to be read in conjunction with the caveat that such access is granted only in so far as it is permitted by each party's internal rules governing the access to these programmes and activities. ${ }^{51}$

With regard to licensing practices, the CARIFORUM-EC EPA requires EPA parties to take measures to prevent and control certain licensing practices or conditions pertaining to intellectual property rights. ${ }^{52}$ The licensing practices that are meant to be controlled are those that may adversely affect the international transfer of technology, and may constitute an abuse of intellectual property rights by right holders, or an abuse of obvious information asymmetries in the negotiation of licenses. According to Malcolm Spence, the technical negotiator of IP issues during the EPA negotiations, this provision is meant to avoid certain situations that have arisen in the past in CARIFORUM States. Small firms in developing countries found themselves in situations in which licensing agreements had already been concluded before the product was protected by a form of intellectual property in CARIFORUM States' markets. Another scenario was that licensing agreements had still been concluded even though the product was running out of protection and was about to enter into the public domain. Furthermore, CARIFORUM States were eager to prevent agreements in which innovations made by the licensee become the

\footnotetext{
49 Abbott (2014), p. 168; Shabalala (2008); Third World Network (2009), p. 9.

50 These refer to the so-called Seventh Framework Programmes (FP7) which are aimed at encouraging greater innovation.

${ }^{51}$ In the FP7 programmes, only firms established in disadvantaged and outermost regions of the European Union, as well as those established in neighbouring states which participate in the European Neighbourhood Policy, are eligible for participation. As Malcolm Spence pointed out during the negotiations, CARIFORUM States indeed are neighbouring states to the French Caribbean Overseas Regions and other EU territories in the Caribbean and should therefore benefit from participation.

52 See Art. 142.2 CARIFORUM-EC EPA.
} 
property of the right holder. ${ }^{53}$ To a certain extent, this goal has been achieved as parties are obliged to prevent and control these practices and because the provision addresses the issue of information asymmetries. ${ }^{54}$ On the other hand, the provision has been criticized because it fails to set up specific rules on how to address these practices. ${ }^{55}$ Nevertheless, even though the rules are not clearly defined yet, they provide room to address specific actions in the future.

Also the draft IP chapter of the India-EU BTIA falls short in dealing with the transfer of technology, licensing and cooperation arrangements in a convincing way as its provisions so far are not concrete enough to be meaningful. The EU and India have already agreed to exchange views and information on policies and practices that affect the transfer of technology and to pay attention to the training and development of human capital. ${ }^{56}$ Furthermore, the parties may control licensing and other contractual practices under certain circumstances and the EU shall facilitate and promote the use of incentives for institutions and enterprises to engage in transfer of technology in India. ${ }^{57}$ Overall, the draft IP chapter of the India-EU BTIA contains even less concrete commitments than that concluded with CARIFORUM States or Central American countries. ${ }^{58}$

To sum up, several features of the negotiations of IP chapters in recent EU bilateral and regional trade negotiations have been identified to be unfavourable for DCs. They concern the context of trade negotiations (allowing for trade packages), the process of negotiating (lack of transparency and equal stakeholders' involvement) and the outcome in terms of the IP content (transfer of technology and licensing arrangements). Hence, DCs need to be wary on how to address these circumstances in a way that allows them to make best use of IP protection. The next part will focus on substantive, strategic and structural factors that they should take into consideration when negotiating a BRA with the EU.

\section{What Can Developing Countries Do to Ensure More Technology Transfer- Enhancing Provisions Are Included in the Agreements?}

A group of academics has carried out research at or in collaboration with the Max Planck Institute for Innovation and Competition on IP provisions in bilateral and regional trade agreements. They have drafted a set of Principles for Intellectual Property Provisions in Bilateral and Regional Agreements. The Max Planck Principles not only present an account of what the guiding principles are when IP

\footnotetext{
53 Interview with Malcolm Spence, 8 April 2010, Bridgetown.

54 This mandatory requirement is an improvement compared with the equivalent TRIPS provision: Article 40.2 of the TRIPS Agreement merely establishes a voluntary possibility for WTO Members to install measures against abusive licensing practices and does not yet talk about information asymmetries.

55 Musungu (2009), p. 26.

56 See Art. 5 draft IP chapter India-EU BTIA.

57 The latter two provisions are very similar to the CARIFORUM-EC EPA.

58 The latter refers to concrete programmes in which their respective nationals or firms wish to participate. See Art. 231.3 and 231.4 of the EU Central America AA.
} 
chapters in bilateral trade agreements are negotiated, concluded and implemented. Importantly, they provide practical recommendations as to how countries involved in the negotiations of such agreements, both IP-demanding countries and countries facing IP demands, should approach the phases before negotiations start, the negotiations themselves, the negotiating outcome as well as the interpretation and implementation of the final IP provisions.

\subsection{Coherence Between the International IP System and Other International Law Regimes}

Negotiating partners are well advised to address one of the developments that is aggravated by specific and complex IP provisions in BRAs, namely the creation of a spaghetti bowl of laws that address interrelated subject matters. This problem occurs at two levels: (1) between various systems of international law, and (2) within the international system of IP law. The drafters of the Max Planck Principles propose to use tools available in IP law and general international law to take these interfaces into account. ${ }^{59}$

Between the various systems of international law, different obligations and rights are created at the multilateral, plurilateral, regional and bilateral level that address the same subject matter. Treaties on public health, environment, biological diversity, food security, access to knowledge, human rights and others deal with issues that interconnect with and affect IP laws. Under public international law, countries are required to ensure the consistency between obligations they have entered into in order to avoid conflicts of law. ${ }^{60}$ As a consequence, when countries commit to specific IP obligations in BRAs, they need to respect their international obligations in other international regimes. ${ }^{61}$ One way of taking earlier treaties into account when negotiating new treaties is by including exceptions and limitations that give effect to the concerns expressed in earlier treaties. One option is an Art. XX GATT 1994-type of general exception, which has been included in the CARIFORUM-EC EPA. ${ }^{62,63}$ It lists several public interest situations in which a breach of an obligation can be justified under certain circumstances. Contrary to the same provision in the GATT 1994, this Article is also applicable to the protection and enforcement of IP, which makes it an interesting example. Furthermore, the provisions of a new treaty will be interpreted and implemented in accordance with other relevant rules of international law. ${ }^{64}$ Relevant earlier treaties will hence influence how the IP provisions in the treaty shall be interpreted.

Within the IP law regime, the drafters of the Max Planck Principles recommend countries to sufficiently take into account the concerns expressed in other IP treaties. The public interest-related flexibilities included in TRIPS reflect these concerns and

\footnotetext{
59 Grosse Ruse-Khan (2014), p. 208.

60 See Art. 31(3)(c) Vienna Convention on the Law of Treaties.

61 Max Planck Institute on Innovation and Competition, 2013, principle 20.

62 Moerland (2013), p. 292 ff.

63 See Art. 224 CARIFORUM-EC EPA.

64 See footnote 60.
} 
should therefore be maintained. ${ }^{65}$ Some IP provisions in BRAs have limited the grounds for invoking compulsory licenses for patents or have extended the term of protecting a patent. ${ }^{66}$ Such provisions had a negative impact on the ability of signatories to protect public health domestically and, in particular, to rely on the Doha Declaration on the TRIPS Agreement and Public Health. ${ }^{67}$ Only recently concluded free trade agreements have acknowledged the latter Declaration to its full extent. ${ }^{68}$ More generally, the Max Planck Principles indicate that the interpretation and implementation of IP provisions in BRAs should be based on the balance that Arts. 7 and 8 of TRIPS seek to maintain. In practice, when countries implement provisions that serve the interests of right holders, they shall also maintain the right to draft exceptions, limitations or safeguards that aim at restoring the balance foreseen in Art. 7. ${ }^{69}$ An example is the power of judicial authorities to order the seizure of suspected goods that infringe an IP right. At the same time, the judicial authorities should be granted the power to request a security by the applicant as to protect the defendant and prevent abuse. ${ }^{70}$

\subsection{Appropriate Balance Within the International IP System}

An important part of the Max Planck Principles addresses the power asymmetry between developed and developing countries when negotiating IP rights and obligations. This was certainly the core of the debate as to whether developing countries were effectively able to negotiate IP issues during the Uruguay Round. Without proper knowledge of the issues underlying IP rights and a lack of resources to develop expertise in all of the relevant areas, meaningful negotiations cannot take place. Some developing countries felt that this is exactly what happened during the Uruguay Round.

Clearly, the situation today is different from what it was 20 years ago, but many of the constraints in terms of resources, knowledge and expertise are still relevant for many smaller DCs. ${ }^{71}$ Research on the CARIFORUM-EC EPA negotiations (2002-2007) has shown that capacity constraints and partly a lack of knowledge among national policy-makers and non-state actors is still very common in these countries. $^{72}$ In order to alleviate this power asymmetry, both IP-demanding countries and countries facing IP demands need to adapt their behaviour.

\footnotetext{
65 Max Planck Institute on Innovation and Competition (2013), principle 21.

${ }^{66}$ For extensions of the patent term, see Art. 14.7.6(a) US-Bahrain FTA; Art. 15.9.6(a) US-CAFTA-DR; Art. 17.9.6 US-Chile FTA. For a restriction of grounds to invoke compulsory licenses, see Art. 17.9.7 USAustralia FTA; Art. 4.20 US-Jordan FTA; Art. 16.7.6 US-Singapore FTA.

67 WTO Ministerial Conference (2001).

68 Art. 147.B CARIFORUM-EC EPA; Art. 13 draft IP chapter India-EU BTIA; Art. 3 EU-Canada CETA; Art. 185 EU-Georgia AA; Art. 15.12 US-Panama TPA and Art. 16.13 US-Peru TPA.

69 Max Planck Institute on Innovation and Competition (2013), principle 24.

${ }^{70}$ While the EU Enforcement Directive provides for this safeguard within the EU, recent EU agreements with third countries have not included it. See Art. 9.6 Enforcement Directive 2004/48.

71 Jones (2013).

72 Moerland (2013), p. 532 f.
} 


\subsubsection{Levelling the Playing Field}

The Max Planck Principles recommend levelling the playing field in so far as that is possible. For that, IP-demanding countries are urged to take international principles of development cooperation, the recommendations of the WIPO Development Agenda and the level of development of their negotiating partner into account when formulating their demands. ${ }^{73}$ This is what the EU has asserted to do already in its 2006 Global Europe Strategy and recently re-confirmed in the revised "Strategy for the protection and enforcement of IP rights in third countries" ${ }^{74}$ However, these policy documents do not further explain or provide examples how the BRAs incorporate the level of development when pursuing the stated goal of increasing competitiveness. Also, when examining the content and scope of the IP obligations in the EU's "new generation" bilateral trade agreements, no major differences are apparent in agreements with emerging economies on the one hand or with developing country partners on the other hand..$^{75}$ Therefore, whether the EU already addresses this need sufficiently is doubtful.

IP-demanding countries should also refrain from influencing the implementation of IP obligations. They should provide unconditional financial and impartial technical support for implementing IP obligations, and cede to use unilateral certification or other assessment processes, or the threat to withdraw benefits. ${ }^{76}$ The latter process has been used by the US, the "scrutiny and vetting" of negotiating partners' implementing laws. Accordingly, the US executive branch unilaterally determines whether the laws are satisfactory in order for the agreement to enter into force. Finally, the negotiated text should include (a) appropriate transitional periods and (b) a review clause whereby the impact of its implementation, in particular its effects on all stakeholders, is comprehensively assessed. ${ }^{77}$ The latter should include the option of renegotiating IP provisions in light of the assessment.

\subsubsection{National and Most Favoured Nation Treatment for Flexibilities}

Finally, the Max Planck Principles offer a line of reasoning that aims at balancing the interests of right holders against those of users, competitors and the general public. The TRIPS requires WTO Members to grant national treatment and most favoured nation treatment for the protection of IP. In other words, treatment no less favourable than accorded to (1) its own nationals and (2) any other WTO Member must be applied to the nationals of all other WTO Members. ${ }^{78}$ The concept of "protection of intellectual property" is further defined in footnote 3 of TRIPS to include matters affecting the availability, acquisition, scope, maintenance and enforcement of IP rights as well as those matters affecting their use. The Max

\footnotetext{
73 Max Planck Institute on Innovation and Competition (2013), principle 11.

74 European Commission (2012), p. 8 and 15; European Commission (2006), p. 12; European Commission (2014), p. 15.

75 Heron and Siles-Brügge (2012).

76 Max Planck Institute on Innovation and Competition (2013), principles 27 and 29.

77 Max Planck Institute on Innovation and Competition (2013), principle 22.

78 See Art. 3 and 4 TRIPS Agreement.
} 
Planck Principles suggest that this concept is not limited to strictu sensu obligations. Rather, it encompasses also exceptions, limitations and other safeguards balancing the interests of right holders, users, competitors and the public at large. ${ }^{79}$ Hence, where IP-demanding countries have agreed to specific exceptions or limitations in other BRAs, a negotiating party should also be able to rely on these concessions. Such analogy, however, can only be drawn if it is at a similar state of development as the country that benefited from these flexibilities under the other BRA.

While it is unclear whether such interpretation of the national treatment and most favoured nation treatment obligations is legally bulletproof, negotiating partners can use such flexibilities agreed elsewhere as a bargaining tool. An example where such a strategy has been used are the provisions on the transfer of technology agreed upon in the CARIFORUM-EC EPA. ${ }^{80}$ Subsequent negotiating partners of the EU, in particular India and Central American countries, ${ }^{81}$ have used the CARIFORUM-EC EPA as a source of inspiration and proposed these provisions on technology transfer for the agreement under negotiation.

\subsection{Flexibility in IP Provisions in BRAs}

In view of the fact that the IP provisions in BRAs tend to erode the policy space provided for in TRIPS, parties to these BRAs are less able to draft IP laws that reflect domestic preferences and that are able to adapt to changing circumstances. ${ }^{82}$ In order to avoid this situation, the IP provisions included in BRAs should respect the following principles.

First, provisions demanding strong IP protection should be sufficiently flexible to take into account the socio-economic situation and needs of both parties. ${ }^{83}$ This is imperative where legal norms from the domestic system of the IP-demanding country are included in the BRA. An example of making obligations more flexible are "best endeavour" obligations. These rather soft obligations will set out that parties should strive to fulfil the obligation, rather than an obligation to fulfil it. They are commonly used in the context of obligations to accede to multilateral agreements. ${ }^{84}$ However, if a party does not achieve this goal, it is not necessarily in violation of its respondent under the agreement. Should a party be challenged on this point, it is the complainant who has to prove that the respondent failed to endeavour, e.g. acceding to the multilateral agreement. This could be rather difficult to prove.

Second, the public interest-related flexibilities included in TRIPS should not be undermined. ${ }^{85}$ These flexible norms provide policy space in domestic implementation or limit IP protection through so called "ceilings". Ceilings are the opposite

\footnotetext{
79 Max Planck Institute on Innovation and Competition (2013), principle 25.

80 See Art. 142.2 and 142.3 CARIFORUM-EC EPA.

81 See Art. 5.2 and 5.3 draft IP chapter India-EU BTIA; Art. 231.3 und 231.4 EU-Central America AA.

82 Max Planck Institute on Innovation and Competition (2013), principle 6.

83 Max Planck Institute on Innovation and Competition (2013), principle 18.

${ }^{84}$ For example, CARIFORUM countries shall endeavour to accede to the Madrid Protocol or the Singapore Treaty. See Art. 144.E CARIFORUM-EC EPA.

85 Max Planck Institute on Innovation and Competition (2013), principle 21.
} 
of "floors", the latter being very common in agreements where minimum standards are agreed upon. A ceiling provides a (binding) maximum level of protection that countries can offer in their national law. ${ }^{86}$ Examples are contained in the limitation of the scope of protected subject matter (Art. 9.1 of the TRIPS that excludes ideas from copyright protection), (mandatory) exceptions to exclusive rights (Art. 10.1 of the Berne Convention makes it an obligation to make quotations permissible) or indirect limitations of right holders' rights by granting a right of coexistence to other signs (trade mark holders in the EU sui generis GI system must accept a limitation of their rights). ${ }^{87}$

\subsection{Inclusiveness in the Negotiating Process and Legitimacy of the Negotiating Outcome}

Finally, the Max Planck Principles highlight the importance of ensuring the participation of multiple stakeholders in the negotiating process. They should be provided with meaningful and equal opportunities to influence the negotiated outcome. ${ }^{88}$ The lack of such inclusiveness has been criticized by the general public in several negotiations of BRAs. ${ }^{89}$ It is, however, through non-discriminatory participation by all stakeholders and meaningful and equal opportunities to comment on draft texts (including publicly elected bodies) that a country can ensure an open and transparent process. ${ }^{90}$ Such a process, together with an impact assessment, is more likely to produce an outcome that reflects important interests in society and that can create legitimacy. Legitimacy of course also depends on how negotiators are able to bargain for e.g. flexible IP provisions, respect for the publicinterest-related flexibilities in the TRIPS, package deals favourable to their country and appropriate transition periods. Only in combination, society is most likely to accept the negotiated outcome and also respect it.

\subsection{Influencing Negotiations Is About Increasing Bargaining Power}

In order to follow and adopt the above recommendations on the interaction with the other negotiating partner, negotiators of DCs need to be able to exercise a certain bargaining power during the negotiations with the EU and the US. It is not selfevident that they dispose of such bargaining power seen the power asymmetry between them and the EU or US. The remainder of this article will address structural factors that can influence negotiators' bargaining power in international, in particular in bilateral and regional, negotiations and the negotiation strategies they choose. $^{91}$

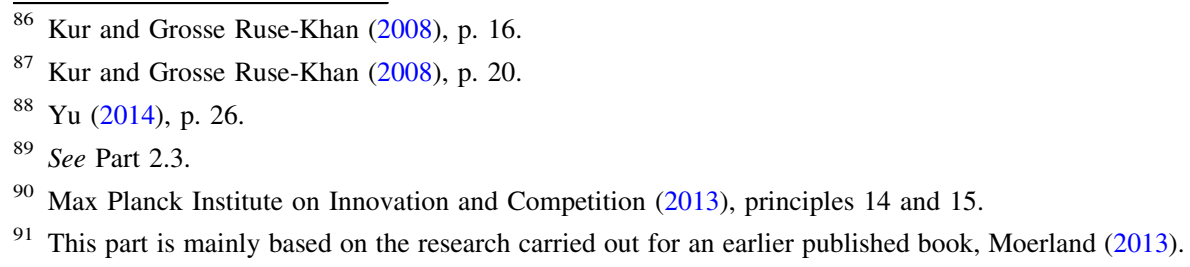




\subsubsection{Structural Factors}

The underlying theoretical framework that allows us to hypothesize about the bargaining power $^{92}$ of negotiators combines liberal theories of international relations with the logic of two-level games. Liberal approaches to international relations, in particular society-centred theories, emphasize that the preferences of domestic actors are crucial to explain why countries coordinate their policies on specific issues at certain times. ${ }^{93}$ Accordingly, states are no unitary actors with a single actor at the top making final decisions, but composed of actors with varying preferences, who share power over decision making. ${ }^{94}$ Individuals and groups in this process do not have equal influence on state policy; ${ }^{95}$ rather, government and political institutions are captive to special interest groups and will create a bias in favour of certain actors and particular preferences. ${ }^{96}$ As preferences of domestic actors are likely to differ from each other, it is a matter of domestic politics to determine which preferences of which actors will prevail in the final policy choices on particular issues. ${ }^{97}$

The structure of domestic preferences plays an important role for the negotiator's negotiating autonomy and bargaining power. ${ }^{98}$ Putnam's two-level game approach established that domestic preferences and the institutional set-up influence negotiating partners' bargaining power. ${ }^{99}$ Putnam-and subsequent research that follows his model-presume that domestic political institutions enable domestic preferences to shape policymaking. While his assumptions may hold true in most cases of "advanced industrial states", ${ }^{100}$ the same does not necessarily apply in other contexts, such as developing countries. The possibility for domestic constituents to participate in policymaking, the political accountability of policymakers and more generally, the level of democracy of a country therefore matter when applying the two-level approach. ${ }^{101}$ Most of the countries in the Caribbean region reveal a relatively high level of participation of domestic constituents and political accountability of policy-makers. ${ }^{102}$

\footnotetext{
92 Bargaining power is hereby understood as the ability of a negotiator to exert influence over another party in a negotiation in order to achieve an outcome that is closest to his maximum negotiating position.

93 Milner (1997), p. 9.

94 Milner (1997), p. 11.

95 Moravcsik (1997), p. 518.

96 Milner (1997), p. 45.

97 Meunier (2007), p. 45.

98 Milner (1997), p. 11.

99 Putnam (1988).

100 Patterson (1997), p. 143.

101 Relevant indicators are the International Country Risk Guide (ICRG) indicator "voice and accountability" that includes measures for "military in politics" and "democratic accountability" (0-1) and the Democracy Index that measures the state of democracy in 167 countries (scale 1-10), http://www. eiu.com.

102 On average, in 2007, the seven, respectively six, covered Caribbean countries scored 0.7 on the ICRG voice and accountability indicator and 6.25 on the Democracy Index.
} 
Putnam's analytical framework can be best illustrated by a metaphor of two separate tables that symbolize the interaction between domestic politics and international negotiations. When a negotiator is at the international table bargaining with her/his foreign counterparts, (s)he can only give as much as the constituents at the domestic table will accept. At the same time, any amendment made at the domestic table must be signed by all negotiators at the international table.

According to the two-level game logic, the position of the international negotiator is determined by her/his domestic "win-set". The domestic win-set is defined as the set of all possible international agreements that can gain the necessary majority among the domestic constituents. ${ }^{103}$ Putnam's basic argument is that the size of the domestic win-set determines the likelihood of reaching an international agreement. ${ }^{104}$ An international agreement is only possible where the domestic winsets of all negotiating parties overlap. The bigger their sizes, the more likely it is that they overlap.

The second basic argument presented by Putnam is that the size of the domestic win-set determines the degree of negotiating autonomy, which in itself has an impact on the bargaining power of the negotiator. ${ }^{105}$ In the case of a small domestic win-set, the negotiator is tied to few acceptable outcomes for an agreement. Since (s)he cannot compromise much, her/his small negotiating autonomy can be a bargaining advantage at the international table, even though this finding may be counterintuitive at first sight. In other words, the smaller the win-set and the negotiating autonomy of a negotiator, the bigger her/his bargaining power. The structural constraint of few acceptable outcomes becomes a bargaining advantage. On the other hand, where the domestic win-set and the negotiator's autonomy are large, the negotiator's bargaining power will be small. Even though the negotiator has much more autonomy as to which tactics and strategies to apply in the international negotiations, the large negotiating autonomy allows the other party to push her/him around by asking several concessions.

Research carried out on the negotiations of the EC-CARIFORUM EPA showed that the IP negotiator for CARIFORUM countries had a large negotiating autonomy due to a large domestic win-set. ${ }^{106}$ In that case, the analysis of non-state actors' preferences on IP protection in the EPA had shown that there were only very few non-state actors that had an interest in IP issues regulated through the EPA. In addition, among those few interested actors, only less than half had specific interests in various fields of IP protection. These interests mostly did not conflict with each other. Overall, these factors allowed for a classification of the win-set as large. At the same time, the negotiating autonomy of the negotiator was also classified as being large, due to the following factors: (1) a lack of non-state actors' preferences on IP issues; (2) a strong reliance on the expertise of the negotiating team in all stages of the policymaking process; (3) an asymmetry of knowledge between the

\footnotetext{
103 Putnam (1988), p. 432 and 437.

104 Putnam (1988), p. 437.

105 Putnam (1988), p. 440.

106 Moerland (2013), p. 409.
} 
experts in the negotiating team and CARIFORUM officials; and (4) a strong personality of the technical negotiator for IP issues. ${ }^{107}$

Judging from the final provisions, CARIFORUM States supposedly had a strong bargaining power with regard to the link of innovation and IP, the transfer of technology, the protection of plant varieties, genetic resources and traditional knowledge. On the other hand, in the areas of design protection and enforcement matters, CARIFORUM countries were less able to preserve their interests. These results are not entirely in conformity with the expectations derived from Putnam's second hypothesis. Since the domestic win-set of the negotiator was large in general, one would have expected a small bargaining power in general.

What could explain the strong bargaining power in the areas innovation, transfer of technology and the protection of genetic resources and traditional knowledge are the negotiator's new and innovative concepts, which the EU had not expected. The strong bargaining power in the area of plant variety protection, on the other hand, may be explained by the preferences and influence of a regional actor (the West Indies Central Sugar Cane Breeding Station), who was the only non-state actor that has communicated his specific and strong preferences to the regional negotiating team. Finally, the weak bargaining power in the area of enforcement standards is one example in which the hypothesis seems to fit: very few preferences existed in the area of enforcement, therefore the negotiator's negotiating autonomy was large and his bargaining power small.

\subsubsection{Negotiating Strategies}

Where domestic win-sets are large enough, international negotiators have some negotiating autonomy to use negotiating strategies that are meant to increase their bargaining power. Strategy in that sense means "a set of behaviours or tactics that are observable in principle and associated with a plan to achieve some objective through negotiation". 108

In most cases, negotiators use a mixed strategy that combines elements that seek a common solution to the problem at hand (value-creating) with actions that place little emphasis on joint gains (value-claiming). Examples of value-creating actions are sharing information relatively openly, proposing to exchange concessions, or the agreement to treat partial agreements as provisional until all issues are settled. ${ }^{109}$ Examples of value-claiming elements are high demands, refusing all concessions, exaggerating one's minimum needs, manipulating information or making threats.

Issue linkage and making side payments are frequently used courses of action found in almost every strategy and negotiation. This is so because there are very few agreements that pertain to only a single issue. ${ }^{110}$ A prominent example of an issue linkage in the area of IP protection is the inclusion of the TRIPS into the GATT framework. The US used a clearly value-claiming strategy to agree on international

\footnotetext{
107 Moerland (2013), p. 587.

108 Odell (2006), p. 15.

109 Odell (2000), p. 34; 2006, p. 16.

110 Odell (2000), p. 37.
} 
standards of IP protection that would become part of the then founded WTO. Particularly developing countries only accepted this inclusion in return for the liberalization of trade restrictions on textiles and clothing exports from developing countries. ${ }^{111}$ But also DCs can use issue linkage in their advantage, as the adoption of the Doha Declaration on the TRIPS Agreement and Public Health has shown.

The strategy of "tying hands" 112 is sometimes used by negotiators when the domestic win-set is large and they choose to provide strategic misinformation about the size of the win-set. At the same time, such a strategy runs the risk of provoking a stalemate if the pretended point of resistance (that is the point where a nonagreement becomes more valuable than an agreement) goes beyond the ability of the other to concede. ${ }^{113}$ In practice, little evidence exists that this strategy is used effectively by governments. ${ }^{114}$ One of the few examples where the strategy is successfully used is the case of EU negotiators, which have been reported to increase their bargaining power by referring to their complicated structure of competences. ${ }^{115}$ DCs are therefore well advised to be aware that their partners may misrepresent their true point of resistance in order to increase their bargaining power. At the same time, they themselves could make use of this mechanism by making domestic constraints explicit in negotiations in order to push the other party closer to one's own preferences.

A very powerful tool to increase one's bargaining power is to commission an independent impact assessment, the outcome of which can be used as part of the negotiating strategy "tying hands". Such an impact assessment would assess what implications the IP demands will have for (1) public interests, (2) the realization of human rights, and (3) the financial burdens and implementation costs they entail. ${ }^{116}$ Accordingly, negotiators are able to hide behind the independent report when demands are made to which the assessment clearly relates severe consequences for public interests; it would not be possible for them to justify a concession that may have severe consequences towards the domestic public. The EU traditionally carries out such sustainability impact assessments for the agreements to be concluded, even though IP protection does not always receive a lot of attention; ${ }^{117}$ this is far less the case for the negotiating partners of the EU. ${ }^{118}$

A more concrete course of action that has proven successful in negotiations of highly technical areas such as intellectual property protection is to develop a proactive IP agenda through consultations with domestic stakeholders and impact

\footnotetext{
111 Bayne and Woolcock (2003), p. 39.

112 Campbell (1976), p. 62.

113 Schelling (1960), p. 28.

114 Evans (1993), p. 399. Peter Evans concludes that the eleven case studies, which were supposed to explore Putnam's two-level game logic further, provided evidence that the strategy of "tying hands" "is infrequently attempted and usually not effective.".

115 Meunier (2007), p. 53.

116 Max Planck Institute on Innovation and Competition (2013), principle 16.

117 European Commission (2013).

118 Neither CARIFORUM States nor India has carried out any impact assessment on the possible implications of the IPR chapter in the bilateral agreement negotiated with the EU.
} 
assessments. ${ }^{119}$ Defining one's own offensive interests is necessary in order to know what to give and what to take in negotiations. They define the negotiating position, allow countries facing IP demands to confront their negotiating partner with their own demands, and to enable a dialogue between the two sides. Research carried out on the negotiations of the CARIFORUM-EC EPA showed that in the areas where CARIFORUM countries had identified offensive interests, the outcome of the agreement was more often in line with their interests than in areas of defensive interests. ${ }^{120}$ This outcome is similar for the negotiations between the EU and India: India has taken a firm stance on several IP areas negotiated in the EU-India BTIA, such as enforcement standards, plant variety protection, GIs and the protection of traditional knowledge, and so far has been lenient to accept provisions that would go against that negotiating position.

For example, CARIFORUM countries were able to "surprise" the EU with the idea to embed intellectual property in the context of innovation and therefore give the IP obligations a different context. The rationale of linking intellectual property to innovation is incorporated in Art. 131 of the EPA. Accordingly, the contracting parties agree that the protection and enforcement of intellectual property plays a key role in fostering innovation and creativity. Innovation and creativity, in their turn, are crucial in achieving improved competitiveness and sustainable development.

According to CARIFORUM States, innovation had to be understood as a broad concept which includes the creative industries in addition to science and technology, thereby not limiting the concept to the EU's reading of it, merely encompassing science and technology. Next to securing this understanding of innovation, the main objective in relation to innovation was to discuss IP protection only in the framework of and as a quid pro quo for improving the levels of innovation in specific areas of development interests to CARIFORUM States through concrete measures. ${ }^{121}$ For example, the protection for designs was to be countered with a provision on the establishment on design centres; commitments to comply with the WIPO Internet Treaties were to be tied to market access in the area of services to enable the small entertainer to benefit. ${ }^{122}$ In other words, their goal was "to ensure an appropriate balance between the level of protection granted to intellectual property rights and the level of development of CARIFORUM economies, in particular the level of innovation." 123

In this line of thinking, when setting higher standards of intellectual property protection, the parties agreed that such IP standards must always be appropriate to the parties' levels of development. ${ }^{124}$ This statement acknowledges the need for differentiated levels of protection, which take into account different levels of development.

\footnotetext{
119 Max Planck Institute on Innovation and Competition (2013), principles 13 and 16.

120 Moerland (2013), p. 557.

121 Spence (2010), para. 17.

122 Spence (2009), p. 2.

123 Spence (2009), p. 2.

124 See Art. 131.2 of the CARIFORUM-EC EPA.
} 
Another example of offensive interests is the provision on the protection of traditional knowledge and genetic resources. The CARIFORUM-EC EPA is the first European bilateral trade agreement that deals with the relationship between patent protection and the protection for genetic resources traditional knowledge and folklore. At the heart of the protection of genetic resources and traditional knowledge lies the conflict that has arisen in the past between the implementation of TRIPS patent rules and the rules on the protection of biodiversity in the Convention on Biological Diversity. The conflict becomes evident when companies use biological material or traditional knowledge as the basis for new inventions on which they are granted patent protection. The countries of origin of this genetic material or traditional knowledge feel that it is unjust that foreign companies can obtain property rights on such inventions without displaying the origin of the material, having asked for approval or sharing the benefits with them.

In Art. 150.3 of the CARIFORUM-EC EPA, the contracting parties of the CARIFORUM-EC EPA agree to implement the patent provisions of the EPA and the Convention on Biological Diversity in a mutually supportive way; in Art. 150.4, the parties agree that they may require, as a necessary aspect of the administrative requirements for a patent application, the identification of the sources of the biological material used by the applicant. In this regard, the provision provides a precedent of a bilateral commitment in addressing important issues related to the protection of biological diversity and traditional knowledge, but it does not yet help to find a general solution to the matter. In international fora such as the WIPO Intergovernmental Committee on Intellectual Property and Genetic Resources, Traditional Knowledge and Folklore, the possibility to require such disclosure is not disputed. The legal problem with regard to the relationship between the TRIPS Agreement and the CBD is about whether countries should be under an obligation to adopt such procedures as a binding international obligation. Nevertheless, this first welcomed attempt to addressing the matter bilaterally was taken up in the EUColombia-Peru FTA and the proposed text by India used the CARIFORUM-EC EPA and the commitments were taken a step further. ${ }^{125}$

The latter line of action should be part of a pro-active IP agenda: proposing already drafted legal provisions from other EU agreements to the EU to be included in the negotiated IP chapter as well. For example, Central American countries, Peru, Colombia and India used, or are still using, this strategy in their negotiations with the EU. They have put forward provisions in the areas of technology transfer, ${ }^{126}$ innovation, ${ }^{127}$ and the protection of traditional knowledge and genetic resources, as explained above, which have been inspired by the CARIFORUM-EC EPA.

\footnotetext{
125 Art. 210 of the EU- Colombia-Peru FTA and Art. 10 of the draft IP chapter of the India-EU BTIA as proposed by India elaborated these provisions even further.

126 Arts. 142.2 and 142.3 of the CARIFORUM-EC EPA have been included in Arts. 5.2 and 3.2 of the draft IP chapter of the India-EU BTIA as proposed by India, as well as in Arts. 231.3 und 231.4 of the EU-Central America AA.

127 Art. 1.1 of the draft IP chapter of the India-EU BTIA as proposed by India places intellectual property in the context of innovation, creativity and competitiveness, identical to Art. 131 of the CARIFORUMEC EPA.
} 


\section{Conclusions}

Developing countries, when negotiating bilateral and regional agreements with the US and the EU, are confronted with high demands regarding the protection and enforcement of IP. In many cases, the process of negotiations and the power asymmetries have a strong impact on the outcome of the agreement: the analysis of recent EU agreements has shown that identical provisions to EU legislation are included in the text, which leave very little policy space to take into account domestic preferences. In certain cases, the scope of protection agreed upon even goes beyond the protection the EU applies internally.

At the heart of this article was to provide substantive, procedural and contextual recommendations as to how the challenges present in bilateral and regional negotiations can be addressed by DCs. The context of trade negotiations easily enables trade deals that trade IP standards against concessions in other areas of trade that are perceived to be more important. DCs should therefore define upfront their own proactive IP agenda and carry out impact assessments of the proposed IP standards in order to strengthen their bargaining power.

Negotiations of bilateral and regional agreements are mostly carried out in secrecy and without equal participation of all interested stakeholders in society. In order to allow for meaningful input from and debate by society, negotiating partners should ensure that sufficiently detailed and timely information on the content of the agreement is made available through public sources. This is a precondition for stakeholders to form their opinion on relevant issues. Furthermore, the process of negotiations must be inclusive for all relevant stakeholders so that they have meaningful and equal opportunities to influence the negotiated outcome.

The provisions included in IP chapters of EU bilateral and regional agreements and US FTAs, often constitute legal transplants with little flexibility to take domestic preferences into account. DCs are therefore well advised to preserve the public interest-related flexibilities in TRIPS. Further, soft instead of hard obligations, appropriate transitional periods and procedural safeguards should be included where possible.

Following these recommendations strongly depends on countries' bargaining power and negotiation strategies that they make use of. In this article, the argument was made that the bargaining power of DCs strongly depends on structural and to a lesser extent on strategic factors. In particular, the structure of domestic preferences determines the negotiating autonomy of the negotiator: if only few, hardly specific and homogeneous preferences exist at the domestic level, the autonomy of the negotiator is large as there is a rather wide range of possible international agreements that will be supported by domestic constituents. However, a large negotiating autonomy also means that the negotiator can be pushed around by his counterpart (as there are many points to which he could be pushed to agree). Only if (s)he is able to misrepresent the size of her/his domestic win-set to the other party, can her/his bargaining power become bigger. DCs should be aware of these structural constraints that affect both their own bargaining power and that of their negotiating partners. 
Also strategic behavior can contribute to increasing one's bargaining power. Developing a pro-active IP agenda, with clearly defined areas of offensive interests and already drafted legal provisions that can be included in the IP chapter, has proven to be effective in achieving the level of protection or the aimed for context as defined in the offensive interests.

Open Access This article is distributed under the terms of the Creative Commons Attribution 4.0 International License (http://creativecommons.org/licenses/by/4.0/), which permits unrestricted use, distribution, and reproduction in any medium, provided you give appropriate credit to the original author(s) and the source, provide a link to the Creative Commons license, and indicate if changes were made.

\section{References}

Abbott FM (2014) Trade costs and shadow benefits: EU economic partnership agreements as models for progressive development of international IP law. In: Drexl J, Grosse Ruse-Khan H, Nadde-Phlix S (eds) EU bilateral trade agreements and intellectual property: for better or worse?, vol 20. Springer, Berlin, pp 159-170

Abbott FM (2004) The Doha Declaration on the TRIPS Agreement and Public Health and the contradictory trend in bilateral and regional free trade agreements. (Occasional Paper No. 14). Geneva: QUNO

Bayne N, Woolcock S (2003) The new economic diplomacy: decision-making and negotiation in international economic relations. Ashgate, Hampshire

BIOTHAI (2008) Fighting FTAs: the experience in Thailand. In: bilaterals.org, BIOTHAI, GRAIN (eds) Fighting FTAs: the growing resistance to bilateral free trade investment agreements. pp. 36-43

Campbell JC (ed) (1976) Successful negotiation: Trieste 1954: an appraisal by the five participants. Princeton University Press, Princeton

El-Said M (2007) The European TRIPS-plus model and the Arab world: from co-operation to association-a new era in the global IPRs regime. Liverpool Law Rev 27:143-174

European Commission (2006) Global Europe: competing in the world. Document number COM 567. Directorate General for Trade, Brussels

European Commission (2012) Trade, growth and development. Tailoring trade and investment policy for those countries most in need. Document number SEC 87. Directorate General for Trade, Brussels

European Commission (2013) Sustainability Impact Assessments Retrieved 6 February 2017, from http:// ec.europa.eu/trade/policy/policy-making/analysis/sustainability-impact-assessments/

European Commission (2014) Trade, growth and intellectual property-strategy for the protection and enforcement of intellectual property rights in third countries. Document number COM 389. Directorate General for Trade, Brussels

Evans PB (1993) Building an integrative aprroach to international and domestic politics: reflections and projections. In: Evans PB, Jacobson HK, Putnam RD (eds) Double-edged diplomacy: international bargaining and domestic politics. University of California Press, Berkeley

Grosse Ruse-Khan H (2014) Principles for intellectual property provisions in bilateral and regional agreements. EIPR 36(4):207-211

Hassan E, Ohid Y, Diepeveen S (2010) Intellectual property and developing countries: a review of the literature. (Rand Europe. Retrieved from http://www.rand.org/content/dam/rand/pubs/technical_ reports/2010/RAND_TR804.pdf (31 March 2017)

Heron T, Siles-Brügge G (2012) Competitive liberalization and the 'Global Europe' services and investment agenda: locating the commercial drivers of the EU-ACP economic partnership agreements. J Common Mark Stud 50(2):250-266

Jones E (2013) Negotiating against the odds: a guide for trade negotiators from developing countries. Palgrave Macmillan, Basingstoke

Kuanpoth J (2006) Negotiations toward a free trade area: US demands for greater IPR privileges Retrieved 01.06.2007, from http://www.grain.org/rights/tripsplus.cfm

Kur A, Grosse Ruse-Khan H (2008) Enough is enough-the notion of binding ceilings in international intellectual property protection. Max Planck Institute for Intellectual Property, Competition and Tax Law Research Paper Series 09-01 
Maskus KE (2006) Observations on the intellectual property component of the European Commission's new trade policy. Aussenwirtschaft 61(4):459-469

Max Planck Institute on Innovation and Competition (2013) Principles for intellectual property provisions in bilateral and regional agreements. Retrieved 6 Feb 2017, from http://www.ip.mpg.de/fileadmin/ ipmpg/content/forschung_aktuell/06_principles_for_intellectua/principles_for_ip_provisions_in_ bilateral_and_regional_agreements_final1.pdf

Meunier S (2007) Trading voices: the European Union in international commercial negotiations. Princeton University Press, Princeton

Milner H (1997) Interests, institutions, and information: domestic politics and international relations. Princeton University Press, Princeton

Moerland A (2013) Why Jamaica wants to protect Champagne: intellectual property protection in EU bilateral trade agreements. Wolf Legal Publishers, Oisterwijk

Moravcsik A (1997) Taking preferences seriously: a liberal theory of international politics. Int Org 51(4):513-553

Morin J-F (2006) Tripping up TRIPs debates: IP and health in bilateral agreements. Int J Intellect Prop Manag 1-2:37-53

Musungu SF (2009) Innovation and intellectual property in the EC-CARIFORUM EPA: lessons for other ACP Regions. IQsensato Studies, 1

Odell JS (2000) Negotiating the world economy. Cornell University Press, Ithaca

Odell JS (2006) Negotiating trade: developing countries in the WTO and NAFTA. Cambridge University Press, Cambridge

Oxfam America (2003) Make trade fair for Central America: agriculture, investment and intellectual property: three reasons to say no to CAFTA. (Oxfam America Briefing Note 2)

Patterson LA (1997) Agricultural policy reform in the European Community: a three-level game analysis. Int Org 51(01):135-165. doi:10.1162/002081897550320

Putnam RD (1988) Diplomacy and domestic politics: the logic of two-level games. Int Org 42(3):427-460

Roffe P (2014) Intellectual property chapters in free trade agreements: their significance and systemic implications. In: Drexl J, Grosse Ruse-Khan H, Nadde-Phlix S (eds) EU bilateral trade agreements and intellectual property: for better or worse? Springer, Heidelberg, pp 17-40

Rossi F (2006) Free trade agreements and TRIPS-plus measures. Int J Intellect Prop Manag 1(1/ 2): $150-172$

Schelling TC (1960) The strategy of conflict. Harvard University Press, Cambridge

Shabalala D (2008) Intellectual property in European Union economic partnership agreements with the African, Caribbean and Pacific Countries: what way forward after the Cariforum EPA and the interim EPAs? Center for International Environmental Law, Geneva

Spence M (2009) Negotiating trade, innovation and intellectual property: lessons from the CARIFORUM EPA experience from a negotiator's perspective

Spence M (2010) Innovation and intellectual property. Paper presented at the the CARIFORUM-EC economic partnership agreement one year on: regional integration and sustainable development, Barbados. http:// www.delbrb.ec.europa.eu/en/epa/one_year_on/EPA_conference_paper_Malcolm_Spence.pdf

Third World Network (2009) EU EPAs: economic and social development implications: the case of the CARIFORUM-EC Economic Partnership Agreement. Retrieved from http://www.twnside.org.sg (21.11.2012)

US Chamber of Commerce (2017). The roots of innovation: US Chamber International IP Index. (5th edn, February 2017). Global Intellectual Property Center. Retrieved from http://www.theglobalipcenter. com/ipindex2017/ (31 March 2017)

Valdés R, McCann M (2014) Intellectual property provisions in regional trade agreements: revision and update. Economic Research and Statistics Division, WTO Secretariat, Geneva

Vivas-Eugui D (2003) Regional and bilateral agreements and a TRIPS-plus world: the free trade area of the Americas (FTAA). Quaker United Nations Office, Geneva

WTO Ministerial Conference (2001) Declaration on the TRIPS Agreement and public health. (WT/ MIN(01)/DEC/2). World Trade Organisation, Doha

Yu P (2014) The strategic and discursive contributions of the Max Planck Principles for intellectual property provisions in bilateral and regional agreements. Drake Law Rev Discourse 62:20-33 